\title{
Modelling the Societal Division of Added Value Created Through Manufacturing 4.0
}

\author{
Heikki Hiilamo and Henri Aaltonen
}

\section{INTRODUCTION}

Ever since the seminal study by Frey and Osbourne, scholars have engaged in a lively debate on the future of work [1-3]. In this debate, the primary issue discussed has been the expected impact of technological change, which includes broad and vague concepts, such as automation, robotization, ever increasing computing power, Big Data, the penetration of the Internet, the Internet-of-Things, online platforms and artificial intelligence [3-5]. In the context of this chapter, we summarize technological changes under the term Manufacturing 4.0. Irrespective of the term used, one school of thought claims that machines will displace human labour, and not just blue-collar but also white-collar tasks, which will consequently result in major labour-market disruptions [6]. This dystopian vision calls for social policies to protect people and societies from the devastating effects of mass unemployment, although scholars disagree on the scope and rate of change in the labour market. Another school of thought

\footnotetext{
H. Hiilamo $(\bowtie) \bullet$ H. Aaltonen

University of Helsinki, Helsinki, Finland

e-mail: heikki.hiilamo@helsinki.fi; henri.aaltonen@helsinki.fi
}

(C) The Author(s) 2020

M. Collan, K.-E. Michelsen (eds.), Technical, Economic and Societal

Effects of Manufacturing 4.0,

https://doi.org/10.1007/978-3-030-46103-4_11 
emphasizes job polarization, both in terms of wages and employment vulnerability, between routine middle-skilled workers, on the one hand, and low-skilled and high-skilled non-routine workers, on the other. While Manufacturing 4.0 will create benefits and wealth for leading global manufacturing companies that employ automated and robotized manufacturing systems, the replacement of human workers with automation and the geographical shift of manufacturing will potentially create at least temporary waves of unemployment in the manufacturing sector [7].

Under these circumstances, a clear need exists to create systems that allow companies to enjoy the fruits of their investments in new technologies while ensuring the ability of industrial society to cope with these changes. As the networked business models related to Manufacturing 4.0 open a global game, where the location of the tax domicile of a given company becomes a point of optimization, industrial societies may wish to create structures that incentivize rather than discourage the establishment of Manufacturing 4.0 companies. The question of how to find meaningful employment for those at the margins of the labour market already is already of immediate relevance throughout the developed world. However, the debate on the effects of Manufacturing 4.0 has focused mainly on the role of technology, while impacts on other sectors of society, such as societal institutions, including social protection, have gained less attention [8, 9]. Nevertheless, different models of social policy adaptation are already being discussed around the globe [10]. This chapter discusses social policy adaptations that incentivize rather than discourage Manufacturing 4.0 and other technological-change driven disruptions while ensuring the normal functioning of the industrial society.

It is important to note that Manufacturing 4.0 not only threatens social protection in the welfare states. These new technologies also provide welfare states with new untapped opportunities to deliver social security, such as easily updatable income registers and personal social accounts. In addition, it should be recognized that new technologies may enable production near the workforce and sources of raw materials without large-scale investments in the production systems. Larger production entities can be realized through the networking of small and mid-sized local manufacturers, which may reinvigorate semi-urban environments, as local manufacturing maintains and develops current service businesses and creates demand for new services.

This chapter studies the social policy responses to the perceived challenges of Manufacturing 4.0 in three countries with strong 
manufacturing and/or transportation industries and current low unemployment, namely Germany, the Netherlands, and South Korea. These countries were also chosen, because they have experienced lively debates on the effects of Manufacturing 4.0. Two of the countries, namely the Netherlands and Germany are welfare states and they belong to the European Union. Meanwhile, South Korea is a liberal market economy and it is a member of the Association of Southeast Asian Nations.

The analysis is based on expert interviews focusing on four themes: (1) emerging needs and solutions for social protection and employment promotion in the new labour markets of 2030, (2) possibilities to enable production near the workforce and sources of raw materials without large investments in equipment, (3) new ways of delivering social security utilizing new technologies and (4) new innovations to limit the possible labour market disruptions caused by automatization (e.g., basic income).

We begin by describing the context of the debate in the three countries. We then present the methodology and the data. The analysis section is divided into four subsections: early signs of labour-market disruptions, the role of semi-urban environments, new ways of delivering social security, and basic income and other innovations to reform social security. Finally, we discuss our key findings and the ways in which they can contribute to the wider debate on Manufacturing 4.0 and social security.

\section{Economy and Social Contexts}

Traditionally, Germany, the Netherlands and South Korea have possessed strong manufacturing industries. The German manufacturing industry includes the automotive sector, chemicals, metals such as iron and steel, electrical equipment, coal, ships, machine tools, high precision equipment, optics, pharmaceuticals, textiles, and plastic goods [11]. In the Netherlands, the key industrial areas consist of agriculture, the chemical industry, the creative industry, the high-tech industry, energy, and manufacturing industries such as metallurgy, electronics, and life science [12]. The most dominant South Korean manufacturing industries are steel, car manufacturing, shipbuilding, and electronics. South Korea is the world's largest producer of semiconductors.

In 2018, Germany was ranked fifth in the world in terms of nominal GDP; moreover, it enjoyed a GDP growth rate of $1.2 \%$. By comparison, in the same year, the Netherlands was ranked 17th for nominal GDP and 
experienced a GDP growth rate of $1.5 \%$, while South Korea achieved the 14th highest nominal GDP and a 2.5\% GDP growth rate [13].

Germany, in addition, has one of the lowest inflation rates, at around $0.5 \%$. Furthermore, in 2018 it enjoyed an unemployment rate of just $4.2 \%$. Its labour force is composed of 45 million people, of whom $73.8 \%$ are engaged in the service sector, $24.6 \%$ in industry and $1.6 \%$ in the agricultural sector [14]. The Netherlands, in turn, has an inflation rate of $2.5 \%$ (2018) and an unemployment rate of $4 \%$ (2017). The majority of workers are employed in the service sector $(80.6 \%$ in 2015$)$, followed by industry (17.2\% in 2015) and agriculture (1.2\% in 2015) [14]. For South Korea the corresponding figure for inflation is $1.9 \%$ (2017) and for unemployment $3.8 \%$ (2018). In terms of the labour force, $70.6 \%$ work in the service sector, $26 \%$ in industry (2017) and 4.8\% in agriculture (2017) [14]. Figure 1 illustrates the unemployment rates in the three countries.

The automotive industry is one of the main driving forces behind Germany's accelerating economy, and the country is the primary location for innovative car manufacturers and suppliers. Moreover, with the constant growth in aircraft production, aerospace opportunities in Germany seem promising. Furthermore, the chemicals industry, which is one of the largest and oldest industries in Germany, plays an elemental role in the

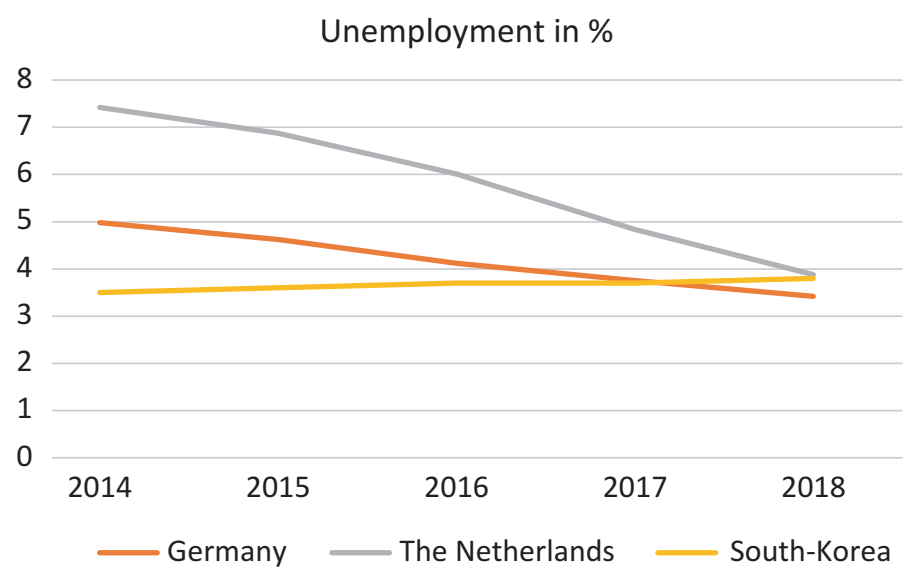

Fig. 1 Unemployment rate in Germany, Netherlands and South Korea between the years 2014-2018 [14]. (Data Source: theglobaleconomy.com (accessed 23 September 2019)) 
country's economy. The key elements of its success include new materials, energy efficient processes, and solution-driven engineering expertise [15].

The German electronics industry is the largest European manufacturer of semiconductors and displays, and the "Silicon Saxony" region is one of the top five semiconductor clusters worldwide. Moreover, Germany's ICT market is the largest in Europe [15]. However, Germany has experienced much discussion about slow digitalization and the immense difficulties of adopting it. Indeed Germany lags significantly behind rest of Europe in digital infrastructure [16]. In the German case, the most salient question is how the country can expand and speed-up its digital infrastructure. At the time of writing (2019), many parts of Germany lack a functioning and reliable digital network. This lack of digital infrastructure hinders economic development and makes Germany an odd country in Europe, with its huge digitally barren tracks of land.

As the world's fifth-largest exporter of goods, the Netherlands occupies a prominent position when it comes to world trade. In 2015, the Netherlands exported goods worth a total of almost USD 668 billion, approximately $3.5 \%$ of total global exports. The Netherlands is also a significant exporter of commercial services-exports of commercial services amounted to USD 189 billion ( $€ 160$ billion) in 2016, placing the country sixth in world rankings. Interestingly, the Netherlands is also the world's second largest exporter of agricultural and food-products after the USA. As well as being a major exporter, the Netherlands also imports large quantities of goods: US\$ 507 billion in 2015 . Accounting for a $3.1 \%$ share of total global imports, the country is the world's eighth-largest importer of goods [17]. Moreover, the Netherlands can be considered a forerunner in adopting to digitalization. Digital technologies - such as big data analysis, artificial intelligence, blockchain, 3D printing, cloud storage and computing, and the Internet of Things-are being used in an increasing number of fields [18].

South Korea, in turn, has experienced remarkable success in combining rapid economic growth with significant reductions in poverty. Per capita income increased from USD 100 in 1963 to almost USD 30,000 in 2018. After two years of economic stagnation, GDP growth in South Korea rose slightly to $3.1 \%$ in 2017 and $2.8 \%$ in 2018 , due to a rebound in household consumption, improvement of the real estate sector and fiscal and monetary stimulus measures. Weakening exports and stagnant investment, however, along with a failure to translate the boom in the chip sector into growth in other industries, are projected to limit economic growth to 
$2.6 \%$ and $2.8 \%$ in 2019 and 2020 respectively [19]. Moreover, although the unemployment rate has been decreasing (3.7\% according to IMF and $3.4 \%$ in December 2018, according to Statistics Korea) the number of irregular workers is extremely high, social inequalities are deepening and social ties are deteriorating [20].

The South Korean government is making a concerted effort to improve the digital skills of the country's workforce. A 2016 report by Barclays jointly ranked South Korea and Estonia first in the world in terms of their ability to equip their workers for the digital economy [21]. This report stated that "Estonia and South Korea are joint leaders in digital empowerment" [21]. It lauded South Korea's world-leading track record in broadband provision in addition to the well-balanced nature and effective implementation of its digital skills policy in formal education as well as adult training, including those out of work. Moreover, the South Korean government has invested heavily in $\mathrm{R} \& \mathrm{D}$, focusing on technology tied to the fourth industrial revolution.

As Table 1 demonstrates, the three countries are fairly similar in terms of poverty and inequality, with the Netherlands enjoying the lowest levels of both poverty and the GINI-Index.

\section{Methodology}

The methodology of this research was qualitative [23]. On the basis of earlier research, we identified four main themes to be investigated. They include signs of disruptions in labour markets caused by Manufacturing 4.0, the role of semi-urban environments in the adoption of Manufacturing

Table 1 Poverty and inequality in Germany, the Netherlands, and South Korea in 2018 [22]

\begin{tabular}{llll}
\hline Country & $\begin{array}{l}\text { Poverty rate with 60\% median income poverty } \\
\text { threshold }\end{array}$ & $\begin{array}{l}\text { GINI } \\
\text { index }\end{array}$ & Dataset \\
\hline Germany & 16.7 & 0.293 & $\begin{array}{l}\text { DE15 } \\
(2015) \\
\text { NL13 } \\
(2013) \\
\text { Netherlands }\end{array}$ \\
Nouth & 20.1 & 0.264 & $\begin{array}{l}\text { KR } 12 \\
(2012)\end{array}$ \\
\hline
\end{tabular}

Data source: Luxembourg Income Study, lisdatacenter.org (accessed 24.10. 2019) 
4.0, new ways of delivering social security utilizing new technologies, and new innovations to limit possible labour-market disruptions caused by automation (e.g., basic income). We then developed a set of questions, which addressed the four major themes relevant for modelling the societal division of added value created through manufacturing 4.0. The selected experts were presented with the questions presented below:

1. Digital innovation's ability to enable machines to accomplish an increasing number of complex tasks is signalling changes to the world of work. Flexible labour markers require flexible social security systems. Can you foresee disruptions in your country's labour markets caused by automation? Even weak signals?

2. New technologies enable production near the workforce and the source of raw materials without large investments in equipment, which may reinvigorate semi-urban environments. Is this something which is visible in your country?

3. Automation, digitalization and artificial intelligence are not only threats to social protection and the welfare state. They also provide social security systems with new untapped opportunities, such as easily updatable income registers and personal social accounts to deliver social security. Which new ways of delivering social security have been discussed in your country?

4. Basic income has been proposed as a solution to labour-market disruptions caused by automation. In which contexts has basic income been discussed in your country? Have any other new innovations been proposed to reform social security (e.g. personal accounts, participation income)?

We used case-studies to analyse the three different countries (Germany, the Netherlands and Korea). In a case-study setting, a well-placed sample can be used to explain a much larger context [24]. Case-studies also offer the methodological possibility to make generalizations from a small group of cases. Thus, even a small sample allows us to compare the differences between the cases and to draw conclusions.

Among a relatively small group of informants, individual experts are in pivotal position within the specific context of their country. To find information on the themes presented above, we identified academic experts who had participated in the debate on Manufacturing 4.0 from universities in Germany, the Netherlands and South Korea. We used Google 
scholar to find research articles and Google to find blogs and conference presentations on adaption to Manufacturing 4.0. Once an expert had been identified, we also used snowballing to identify more experts.

Only a limited number of experts in each country (see Table 2) agreed to participate in the study. After several rounds of requests, we were able to recruit three experts in Germany, one expert in the Netherlands and five experts in South Korea. All the experts were sent the questions presented above. The answers were collected through personal interviews from experts in the Netherlands and South Korea. By contrast, in the case

Table 2 Experts who participated in the study

\begin{tabular}{|c|c|c|c|c|}
\hline Name & Country & $\begin{array}{l}\text { University/ } \\
\text { Affiliation }\end{array}$ & Academic position & $\begin{array}{l}\text { Description of competence } \\
\text { with relevance for } \\
\text { Manufacturing } 4.0\end{array}$ \\
\hline $\begin{array}{l}\text { Martin } \\
\text { Gross }\end{array}$ & Germany & $\begin{array}{l}\text { University of } \\
\text { Tübingen }\end{array}$ & Professor & $\begin{array}{l}\text { Labour market and } \\
\text { social inequality }\end{array}$ \\
\hline $\begin{array}{l}\text { Aljoscha } \\
\text { Jacobi }\end{array}$ & Germany & $\begin{array}{l}\text { Humboldt } \\
\text { University, } \\
\text { Berlin }\end{array}$ & $\begin{array}{l}\text { Assistant professor } \\
\text { of sociology }\end{array}$ & $\begin{array}{l}\text { Labour market and } \\
\text { digitalization }\end{array}$ \\
\hline $\begin{array}{l}\text { Philip } \\
\text { Staab }\end{array}$ & Germany & $\begin{array}{l}\text { Humboldt } \\
\text { University, } \\
\text { Berlin }\end{array}$ & $\begin{array}{l}\text { Professor of } \\
\text { sociology }\end{array}$ & $\begin{array}{l}\text { Digitalization, labour } \\
\text { and industry sociology }\end{array}$ \\
\hline $\begin{array}{l}\text { Minna } \\
\text { van } \\
\text { Gerven }\end{array}$ & Netherlands & $\begin{array}{l}\text { University of } \\
\text { Twente }\end{array}$ & Professor & Welfare states globally \\
\hline $\begin{array}{l}\text { Hyosang } \\
\text { Ahn }\end{array}$ & $\begin{array}{l}\text { South } \\
\text { Korea }\end{array}$ & $\begin{array}{l}\text { Basic Income } \\
\text { Earth } \\
\text { Network in } \\
\text { Korea }\end{array}$ & Executive director & $\begin{array}{l}\text { Basic income and } \\
\text { student activism }\end{array}$ \\
\hline $\begin{array}{l}\text { Young } \\
\text { Jun Choi }\end{array}$ & $\begin{array}{l}\text { South } \\
\text { Korea }\end{array}$ & $\begin{array}{l}\text { Yonsei } \\
\text { University, } \\
\text { Seoul }\end{array}$ & $\begin{array}{l}\text { Professor for public } \\
\text { administration }\end{array}$ & $\begin{array}{l}\text { Planned basic income } \\
\text { experiment for the city } \\
\text { of Seoul }\end{array}$ \\
\hline $\begin{array}{l}\text { Iljin } \\
\text { Hong }\end{array}$ & $\begin{array}{l}\text { South } \\
\text { Korea }\end{array}$ & $\begin{array}{l}\text { Yonsei } \\
\text { University, } \\
\text { Seoul }\end{array}$ & Research professor & $\begin{array}{l}\text { Comparative welfare } \\
\text { state research }\end{array}$ \\
\hline $\begin{array}{l}\text { Nam } \\
\text { Hoon } \\
\text { Kang }\end{array}$ & $\begin{array}{l}\text { South } \\
\text { Korea }\end{array}$ & $\begin{array}{l}\text { Hanshin } \\
\text { University, } \\
\text { Seoul }\end{array}$ & $\begin{array}{l}\text { Professor of } \\
\text { economics }\end{array}$ & $\begin{array}{l}\text { Chair of Basic Income } \\
\text { Earth Network in Korea }\end{array}$ \\
\hline Jun Koo & $\begin{array}{l}\text { South } \\
\text { Korea }\end{array}$ & $\begin{array}{l}\text { Korea } \\
\text { University, } \\
\text { Seoul }\end{array}$ & $\begin{array}{l}\text { Professor of } \\
\text { economics, Dept. of } \\
\text { Public } \\
\text { Administration }\end{array}$ & $\begin{array}{l}\text { Innovation and public } \\
\text { policies, planned basic } \\
\text { income experiment for } \\
\text { the city of Seoul }\end{array}$ \\
\hline
\end{tabular}


of the German experts, the questions were sent and the answers received via email. The language used in the questions and interviews was English, and all but one expert answered in English (one German expert answered in German).

Once the data were collected, we analysed the answers using qualitative content analysis.

\section{AnAlysis}

In the following, we summarize the experts' opinions on signs of labourmarket disruptions, the role of semi-urban environments, new ways to deliver social security, and basic income and other new innovations for social security.

\section{Signs of Disruptions}

Our informants were able to identify early signs of labour-market disruptions, but there was no major loss of jobs in sight in any country. Germany was the country with the weakest signs of disruption. Automation has been a German success story, and consequently German industry has been quick to adapt to new technological innovations. Moreover, the German experts viewed the future as more of a gradual shift than a rapid transformation to Manufacturing 4.0. For example, the manufacturing of automobiles is slowly moving towards the production of electric cars. As one expert put it, "[F]orecasts are always perilous, but if I had to make a bet, I would say that we most likely will see more gradual task-specific change, which will have a strong negative impact only on people with some level of specialized qualifications performing automatable tasks." The focal point in Germany concerns the regulation of platform work, as a divide exists between those whose labour is regulated and those whose labour is relatively free from regulatory control. The question in Germany, as well in the other countries in our sample, is how to identify vulnerable groups and develop measures to include them in future labour markets.

In the Netherlands, few signs exist of drastic labour-market disruptions. The country's unemployment rate has been one of the lowest in the Eurozone for a decade. Moreover, the Netherlands enjoys good digital infrastructure, and its strong position as an export country and its highly educated workforce make the country very able to capitalize on the opportunities created by digitalization. For instance, the Netherlands has 
traditionally featured an extremely strong logistics sector, and the country boasts many cloud-based logistics and innovation-hubs. Dutch society is currently embracing the economic and social opportunities created by digitalization, as well as leveraging the opportunities it has for the public sector, such as for health care, mobility, energy and the food sector. Moreover, signs of sudden disruption have yet to be seen.

The Dutch social security system places a strong emphasis on flexibility. This flexibility allows companies the necessary room for manoeuvre in a small and open economy such as the Netherlands. Moreover, it also helps citizens combine work and family responsibilities without major interventions from the public sector. This flexibility is manifested primarily in the predominance of part time work, which is very common in the Netherlands, especially among women. Part-time work, however, comes with strong social protection and thus cannot be defined as atypical work or involuntary work, as it is in many other European countries. In some sectors, temporary work is in high demand (particularly in the agrisector), and the number of people with temporary contracts (instead of permanent contracts) has been growing across the Dutch labour market. Furthermore, self-employment is also becoming more common in the Netherlands. Together with the rise of platform economies, self-employment has been emphasized as a solution to the challenges of future labour markets in the country.

In essence, the Dutch welfare state is no longer a welfare state but a participation state. The Dutch system expects every citizen to be active and find work in the labour market or engage in some other form of participation outside the labour market. While the degree of participation differs, the aim is activate the unemployed and prepare them for working life. In the Dutch system, municipalities enjoy a great degree of autonomy and thereby the independence to find their own solutions to participation, which can differ greatly from municipality to municipality. The Dutch system emphasizes self-reliance, and if this is insufficient, the family is expected to provide assistance. Nonetheless, if individuals lack the resources to help themselves, the municipality, and in the last resort the state, will provide support.

The Korean experts, in turn, observed that the risk of job losses due automatization was significantly lower in South Korea than in many other countries because of high levels of expertise in the labour force. Korea has already experienced extensive robotization in the manufacturing industry. 
Moreover, robotization and automatization are generally considered a positive change for Korea.

Nevertheless, as large companies dominate Korean industry, SMEs are less adapted to automatization and offering quality jobs. Signs also exist of a growth in unemployment through automatization. Thus, while the Korean economy is growing, this growth is not reflected in a rise in employment. Consequently, contrary to previous growth periods, an accumulation of value is not mirrored in an accumulation of jobs. In addition, service sector jobs are simultaneously disappearing. However, the country's extremely low fertility rate and small number of migrants are reducing the size of the labour force, which helps Korea adapt to the loss of jobs resulting from Manufacturing 4.0.

Minimum income, in turn, has risen in recent years because automation increases the price of human labour. One expert summarized the situation thus: "Minimum income has been increased considerably over the last few years. That incentivize[s] Manufacturing 4.0 since [the] price of human labour increase [s]. Actually [the] minimum income rise has benefitted middle and high income earners whose salaries have increased but has not helped low-income workers who have experienced more unemployment."

\section{Role of Semi-urban Environments}

To date, few signs exist of reinvigorated semi-urban environments in Germany. Moreover, the core urban environment is experiencing high pressure and structural change. Germany currently faces a shortage of skilled labour in many areas, which, in turn, accentuates urbanization. Start-ups are primarily founded in larger cities to attract talent and benefit from cluster-effects. Some developments in the areas surrounding larger cities are evident, but they can be considered part of normal economic development.

Similarly, in the Netherlands, innovations and market developments tend to occur in large cities and triple-helix networks (public, private and knowledge institutions). No stringent segregation of the labour market between urban and rural areas exists in a country as densely populated as the Netherlands. However, in regions such as Zeeland, Friesland and Limburg, job opportunities are scarcer and the population age is higher than in the capital area (Randstad) and other brainport areas (university areas). 
Korea, in turn, is characterized by a dualized labour market, which means it is polarized between large companies and SMEs. Put simply, large companies are investing in new technologies, including robotization, while SMEs are not. Moreover decentralization has occurred. For example, the South Korean city of Unsal already enjoys a higher productivity level than Seoul.

Korea considers itself a global centre of manufacturing, which makes manufacturing 4.0 of paramount importance to the Korean national economy. To maintain a competitive environment for manufacturing companies, Korea continues to invest in robotization and automation. That means robots are replacing human labour, with robot hubs located around existing cities or rising in entirely new locations. As one expert put it, the development "is characterized by a gradual decline in employment by new technology rather than a change in location by new technology".

The Korean population is aging even faster than that of Japan, which means that provincial cities are declining and the population is compressed into large cities. This trend has led to the desolation of rural areas and provinces. Rapid aging also significantly affects welfare, as the life expectancy of Koreans is the highest among OECD countries. This is due to universal health insurance and a vegetable-based diet. As a consequence of Korea's aging population, the dependency ratio is bound to increase.

Rapid aging also causes generational conflict, which is set to intensify in the future. Thus, while pensions can be guaranteed for the older generation, the situation for the following generations remains uncertain. In the words of one expert, "It is becoming more difficult to establish generational justice with existing traditional pension schemes. The burden for young people is getting bigger. This is why basic income is needed".

\section{New Ways to Deliver Social Security}

The debate concerning new social security systems in Germany is dominated by the themes of flexibilization and, as in the 1980s, the possible reduction of working time. The German debate is characterized by two different approaches to social innovations. The first emphasizes the universalizing of existing social policies, which tend to be employmentcentred; i.e. they exclude the self-employed and the economically inactive. Examples include the universalization of public health insurance or minimum pensions. The second approach aims at innovation within employment-centred policies. The Social Democratic Party (SPD), in 
particular, has proposed several ideas. One has been the model of "Arbeitzseitkonten", which would grant employees the opportunity to benefit from the difference between calculated working hours and actual working hours, with the difference to be used later at a time chosen by the employee [25]. In turn, "Lebenschancekredit" [26] is a system designed to give employees the freedom to choose how and when to use their labour hours. Lebenschancekredit is basically a bank account where one store excess working hours. In other words, both schemes provide workers with unconditional access to periods of free time with the right to return to the same, safe position (of which there are far fewer than 40 years ago). Thus, flexible work and flexible free time are at the core of the German discussion.

In Germany, attitudes towards the digitalization of public administration services remain rather sceptical. However, some local administrations have digitized basic public services, such as applications for passports, and drivers' licenses. Interestingly, when the central government was overwhelmed by the task of registering Syrian war refugees and processing their cases, it relied on a mix of expanding services and digitizing the relevant government agency. This progressed to the extent that AI was used to classify refugees. Nevertheless, this move led to a backlash, and thus if applied on a larger scale to all citizens, it would be politically costly. In addition, some steps have been taken towards digitization in public health insurance, but to not in other major federal-level social programmes.

In turn, the digitalization of society is a buzz word in the Dutch debate. Digital government and the digitalisation of public administration have been important goals for recent governments. These include digitalization of the administration of social security. Moreover, a number of e-democracy tools have been made available in the last decade to increase citizen participation and fuel civil-society platform-technology thinking. Moreover, while trade unions are concerned about the effects of digitalization and automatiion on the labour market, they are reasonably positive about digitalization itself and the economic and social opportunities that it offers. Thus, the Dutch approach could be characterized as civil-society platformtechnology thinking. Nonetheless, trade unions remain undecided on which opinion they will adopt vis-a-vis digitalization. Furthermore, Dutch society is waiting to see the kind of stance Brussels will take on the matter before reacting and advancing pragmatically.

By contrast, the central theme in the social security debate in South Korea concerns selectiveness in the social security system. Selectiveness is 
a more costly and hence less effective way to deliver social security than the universalist approach. There is a hope, however, that new technologies will reduce screening costs. The remaining caveat is that a reduction in screening costs does not necessarily mean that the basic needs of the vulnerable are met. Currently, automation is not utilized extensively in delivering social security. There is, however, a strong consensus around increasing coverage and spending in social security. If and when this occurs, new technology can be applied.

\section{Basic Income}

The debate on basic income is at an early stage in Germany. However, a recent shift has occurred from intellectual debates to political debates. Nonetheless, concrete measures are still missing. While basic income is a rather popular concept, which is regularly discussed in the media, and which, according to opinion polls, is supported by roughly half of Germans, the experts participating in our study saw no clear consensus emerging. Moreover, proponents of basic income support it for different and often contradictory reasons, suggesting that any specific model would have weaker approval ratings. Furthermore, support for basic income only weakly aligns with social class or party preferences, making it harder to mobilize voters around the topic.

Two parties, the Greens and SPD, have models of basic income that focus on improving the current social safety net of last resort. One expert described the situation with the following remark: "One SPD model departed widely from the original idea of basic income by demanding that recipients do 'socially beneficial work', i.e. the term 'basic income' was propped [up by] the older concept of a 'social labour market', where the state provides low-skilled jobs for the long-term unemployed". In other words, two strains of thought are found in Germany; the first emphasizes relieving pressure on the state budget, while the second stresses quality of life and the ability to decide the kind of life one wishes to lead.

In the Netherlands, by contrast, municipalities are currently experimenting with basic income. These trials focus on current welfare claimants (social assistance) and therefore go beyond mere 'basic income'. The process has been colourful: The experiments were intended to be launched on May 2017, but they were subsequently delayed. They finally began in June 2018, and are set to conclude in October 2019. The trails aim to provide an alternative approach to social assistance and investigate 
the effects of a different set of rules on claimants of social assistance. In the political debate within the participation-state modus, the experiments are seen as way to increase active participation in labour markets and support those who cannot find work. The current experiments employ different approaches, as Dutch municipalities differ greatly in the ways they enforce participation: whereas some municipalities employ very strict conditions and sanctions, others are far more lenient. At the time of the writing, the results of these recent experiments are not yet known.

The basic income movement in South Korea began from grass-roots societal dissatisfaction. Support for basic income stems from young people's perception of a lack of solidarity among Korean citizens. The basic income debate is, consequently, mostly preoccupied with the situation of young people in society. However, while the city of Seoul planned a basic income experiment for young people, the initiative failed to gain sufficient support. In Korea there are two opposing views on the development of the social security system, a welfarist approach and basic-income approach. Currently, the welfarist perspective, which emphasizes work ethics and the prevention of free riding, remains stronger.

However, Gyenoggi province, with 13 million inhabitants, has begun a basic income programme where all young people will receive 1 million won (around 760 euros) at the age of 24 for one year without any conditions. The Gyenoggi basic income is paid in a local currency which is valid only in this province. Moreover, only SMEs can convert this currency into legal currency. Thus, the aim is both to help young people and support local SMEs. Moreover, this is considered one of the largest pilots with local currency in the world.

In Korea, two additional variations of basic income also exist. One is basic income as land dividend: a policy of imposing a land tax and distributing the income equally among the people. The second variation is targeted at farmers, and is, in effect, participation income. Here, the main aim is to improve the situation of poor farmers.

Gyenoggi's basic income for young people plays a pivotal role in the basic income debate in South Korea. As one expert noted, "The SMEs' business opportunities are less important that what is happening to you [ng] people, changes in young people's attitudes, economic aspects and study choices". If basic income effects a positive change, more young people will move to Gyenoggi province from other parts of the country, and this will significantly increase pressure to implement basic income at a national level. 


\section{Discussion}

The industrial structures and path-dependencies in their social security systems make each of the three countries unique cases. Nonetheless, it is still possible to find similarities between the chosen countries. The analysis above demonstrates a clear need for social policy adaptation to Manufacturing 4.0 in countries with highly developed manufacturing industries and current low unemployment levels. Despite the diverse nature of the concept of social security and the myriad social security schemes in existence around the world, all three countries recognized the necessity to reform their social security systems in the wake of prospective labour-market disruptions. The question is if whether these reforms will be sufficient and when the reforms are needed.

In the German case, no labour-market disruptions were foreseen in the near future because of the robust level of automatization in the country's various industrial sectors. Small and medium-size enterprises (SMEs or Mittelstand) are the backbone of German industry and the source of larger companies' economic might. Nevertheless, the focal point for Germany, as well for the other countries in this study, concerns the regulation of platform work. There is a gap between those whose labour is strictly regulated and those whose labour is more loosely controlled. Digitalization is progressing swiftly for large companies, but many SMEs are struggling in this area. Due to the German federal system, municipalities are in a key position to enhance digital infrastructure, whereas federal bodies play a central role in advancing the path of digitalization.

In the Dutch case, no signs are evident of severe labour-market disruptions. Moreover, this finding is of no surprise. The Netherland's unemployment rate has been one of the lowest in the Eurozone for a decade. Furthermore, the country possesses good digital infrastructure, and its strong position as export country with a highly educated workforce make the Netherlands more than able to capitalize on the opportunities created by digitalization. Thus, the Netherlands has all the ingredients to succeed in digitalization.

In South Korea, the risk of job losses due automation is significantly lower than in many other countries because of the high levels of expertise in the labour force and the decrease in labour supply caused by the country's extremely low birth rate. Korea already enjoys a high level of robotization in the manufacturing industry. Moreover, robotization and automation are generally considered a positive change for Korea. 
Apart from the need to renew their social security systems in response to technological change, all three countries face an ageing population, thus making it harder to finance social security schemes. The countries have all faced various challenges in their past, which they have overcome, but in different ways. This has led to a different perception of how society should deal with unemployment and the renewal of social security schemes.

To date, few signs exist of reinvigorated semi-urban environments in Germany. Furthermore, the country's core urban environment is experiencing high pressure and structural change. Germany currently faces a shortage of skilled labour in many areas, thus larger cities attract much of the potential labour force, enhancing their position to the detriment of smaller towns and rural areas. Similarly, in the Netherlands, innovations and market developments occur in large cities and triple-helix networks (public, private and knowledge institutions). The Netherlands is nonetheless a densely populated country, and consequently urban and rural areas exist in close proximity. However, some areas lag behind the capital area in their pace of change.

The population is ageing in South Korea at a record pace, even faster than that of Japan. Consequently, provincial cities are declining and the population is increasingly centred in large cities. This is leading to the desolation of rural areas and provinces.

The debate concerning new social security systems in Germany is dominated by the themes of flexibilization and, as in the 1980s, the possible reduction of working time. The German debate is characterized by two different approaches to social innovations. The first emphasizes the universalization of existing social policies, which tend to be employmentcentred; i.e. they exclude the self-employed and the economically inactive. The second approach aims at innovation within employment-centred policies. The SPD, in particular, has proposed several ideas to promote inclusive labour markets. In terms of attitudes towards the digitization of public administration services, the climate remains fairly sceptical in Germany. While some steps towards digitization have been taken in public health insurance, other major federal-level social programs have failed to follow suit. This encapsulates the attitude towards new solutions for social security and how one can control the data behind these innovations.

In turn, the buzz word in the Dutch debate is the Digitalization of society. Thus, recent governments have stressed the goals of Digital government and the digitalization of public administration. The Dutch approach could be described as a civil-society platform-technology 
thinking. However, before reacting more forcefully, Dutch society is waiting to see the stance Brussels adopts on digitalization. This summarizes the current Dutch attitude towards digitalization.

The central theme in the social security debate in South Korea, by contrast, concerns selectiveness in the social security system. Selectiveness is costly, and hence represents a less effective means of delivering social security compared to the universalist approach. There is a hope, however, that new technologies will reduce screening costs. Nonetheless, a strong consensus is forming around increasing social security coverage and spending. If and when this transpires, new technology can be applied. Korean society is focused on cost and the efficiency, which are tied to the digitalization of social security.

The three countries' social security systems have been forged over long periods of time in different historical contexts, and this is also reflected in their approach to basic income. The debate on basic income is at an early stage in Germany. However, as previously mentioned, a recent shift has occurred from intellectual debates to political debates, although concrete measures are still lacking. Moreover, while basic income is regularly discussed in the media and, according to opinion polls, enjoys the support of roughly half of Germans, the experts in our study saw no signs of a consensus emerging. Thus, although Germans are pondering the feasibility of basic income for their society, there is little indication of concrete action in the foreseeable future.

As mentioned earlier, the Netherlands is currently experimenting with basic income at a municipal level. These trials focus on current welfare claimants (social assistance) and therefore go beyond mere 'basic income'. In the political debate within the participation-state modus, the experiments are seen as a means of increasing active participation in the labour market and supporting those unable to find work. The current experiments employ different approaches, as Dutch municipalities differ greatly in the ways they enforce participation, with some municipalities employing very strict conditions and sanctions and others being far less stringent. At the time of the writing, the results of these recent experiments are as yet known. Regional diversity is one peculiarity of the Dutch system, where every municipality approaches participation as it sees fit. Nonetheless, participation in working life is the essence in the Dutch welfare state, which can be considered a participation state.

The basic income movement in South Korea began from grass-roots societal dissatisfaction. Support for basic income stems from young 
people's perception of a lack of solidarity among Korean citizens. The basic income debate is, consequently, mostly concerned with the situation of young people in society. This quest for more solidarity is the driver of changes in young Koreans' participation in the labour market. Nonetheless, the Korean labour market is dominated by large conglomerates, and consequently little room exists for innovative, original ideas. However, Korea features two additional variations of basic income. One is basic income as land dividend: a policy of imposing a land tax and distributing the income equally among the people. The second variation is targeted at farmers, and is, in effect, participation income. Here, the main aim is to improve the situation of poor farmers.

\section{Reliability and Validity}

We were only able to recruit a limited number of experts to act as informants for this study. This is unsurprising given that the topic is new and research knowledge has only recently begun to accumulate. The data were collected by both personal interviews and email. However, the same questions were used for both data collection methods. While the selected experts do not constitute a representative sample of all existing expert opinions in their respective countries, given their background and experience we assume that they were able to convey valid information on the topics analysed in this study. Our qualitative research method allowed us to study nuances and create a more coherent picture of the themes than that available in the current literature.

\section{Conclusion}

To conclude, in Germany the main challenge is society's perception that unemployment is primarily a personal issue. Work is abundant, and thus one must merely desire to work. Similarly, the Netherlands is a participation state, where the responsibility for finding work or other means of activation lies with the individual. If a person is unable to cope, help should be sought from the family, then from the municipality and, as a last resort, from the state. By contrast, in South Korea social innovations tend to be locally-driven ad-hoc campaigns, thus making their future somewhat bleak. Consequently, Korea seems to lack an overarching strategy for applying basic income or other social innovations. Only time will tell whether the approaches discussed in this study will provide working 
solutions for citizens struggling to find work and relying on social security schemes and whether the three countries will successfully navigate the paradigm shift to Manufacturing 4.0.

\section{REFERENCES}

1. C. E. Frey and M. Osborne, "The Future of Employment: How Susceptible Are Jobs to Computerisation?" Oxford Martin Programme on Technology and Employment, Sept. 17, 2013.

2. C. E. Frey and M. Osborne, "The Future of Employment: How Susceptible Are Jobs to Computerisation?" Technological Forecasting and Social Change, vol. 114(C), pp. 254-280, 2017.

3. D. Acemoglu and P. Restrepo, "The Race between Man and Machine: Implications of Technology for Growth, Factor Shares, and Employment," American Economic Review, vol. 108, no. 6, pp. 1488-1542, 2018.

4. M. Arntz, T. Gregory and U. Zierahn, "The Risk of Automation for Jobs in OECD Countries: A Comparative Analysis," OECD Social, Employment and Migration., OECD Publishing. Paris, no. 189, 2016.

5. D. Autor, "Why Are There Still So Many Jobs? The History and Future of Workplace Automation," Journal of Economic Perspectives, vol. 29, no. 3, pp. 3-30. 2015.

6. A. Korinek and J. Stiglitz, "Artificial intelligence and its implications for income distribution and unemployment," NBER series, Dec. 2017.

7. J. Cowie and J. Heathcott, "The meanings of deindustrialization," in Beyond the ruins: The meanings of deindustrialization, J. Cowie and J. Heathcott, Eds., ed Ithaca, NY, USA: ILR Press, 2003, pp. 1-15.

8. D. Acemoglu and J. Robinson, Why Nations Fail: The Origins of Power, Prosperity and Poverty. London, England: Profile Books, 2012.

9. D. Acemoglu and J. Robinson, The narrow corridor. States, societies and the fate of liberty. New York, USA: Penguin Press, 2019.

10. H. Hiilamo and K. Komp, "The case for participation income: acknowledging and valuing the diversity of social participation," The political quarterly, vol. 89, pp. 256-261, 2018.

11. B. E. Sawe, "The Economy of Germany," WorldAtlas, April 2017, [Online]. Available: worldatlas.com/articles/the-economy-of-germany.html. Accessed: September 20, 2019.

12. Netherlands Enterprise Agency, "Key Sectors" Holland Trade and Invest [Online]. Available: https://www.hollandtradeandinvest.com/key-sectors. Accessed: September 20, 2019.

13. Gross domestic product (GDP). doi: 10.1787/dc2f7aec-en[Online]. Accessed September 23, 2019. 
14. Global Economy, [Online]. Available: https://www.theglobaleconomy.com Accessed: September 23, 2019.

15. German Trade \& Invest, "Industries in Germany" [Online]. Available: https://www.gtai.de/GTAI/Navigation/EN/Invest/industries.html. Accessed October 24, 2019]

16. K. Schwab, The Fourth Industrial Revolution. Geneva, Switzerland: World Economic Forum, 2016.

17. Netherlands Foreign Investment Agency, "Economic Overview" [Online]. Available: https://investinholland.com/economic-overview/. Accessed: September 20, 2019.

18. Goverment of the Netherlands, "Dutch digitalisation strategy" June 1 , 2018, [Online]. Available: https://www.government.nl/documents/ reports/2018/06/01/dutch-digitalisation-strategy. Accessed: September $20,2019$.

19. Nordea, "South Korea: Economic and Political Overview" February 2020*, [Online]. https://www.nordeatrade.com/fi/explore-new-market/southkorea/economical-context. Accessed: September 20, 2019.

20. C. Kim and S. Lee, "South Korea proposes record budget lifeline for jobs, welfare in 2019" August 28, 2018 [Online]. Available: https://www.reuters. $\mathrm{com} /$ article/us-southkorea-economy-budget/south-korea-proposes-recordbudget-lifeline-for-jobs-welfare-in-2019-idUSKCNILD02Y. Accessed: October 24, 2019.

21. Barclays, "From Inclusion to Empowerment: The Barclays Digital Development Index" July, A 2016 [Online]. Available: https://www.longitude.co.uk/wp-content/uploads/2018/11/Barclays-Digital-DevelopmentIndex.pdf. Accessed: October 24, 2019.

22. Luxembourg Income Study Database (LIS) [Online]. Available https://www. lisdatacenter.org/ Accessed: October 24, 2019.

23. J. Jupille, "Knowing Europe, Metatheory and Methodology in European Union Studies" In Palgrave Advances in European Union Studies, M. Cini and A. Bourne Ed., London, England: Palgrave Macmillan, 2006, pp. 209-232.

24. B. Flyvbjerg, "Five Misunderstandings About Case-Study Research," Qualitative Inquiry, vol. 12, no. 2, pp. 219-245, 2006.

25. Prosoft, “Arbeitszeitkonto, Was ist ein Arbeitszeitkonto?” [Online]. https:// www.prosoft.net/was-ist/arbeitszeitkonto. Accessed: October 24, 2019.

26. S. Mau, "Der Lebenschancenkredit: Ein Modell der Ziehungsrechte für Bildung, Zeitsouveränität und die Absicherung sozialer Risiken," WISO, Friedrich-Ebert-Stiftung, Bonn, 2015. 
Open Access This chapter is licensed under the terms of the Creative Commons Attribution 4.0 International License (http://creativecommons.org/licenses/ by $/ 4.0 /$ ), which permits use, sharing, adaptation, distribution and reproduction in any medium or format, as long as you give appropriate credit to the original author(s) and the source, provide a link to the Creative Commons licence and indicate if changes were made.

The images or other third party material in this chapter are included in the chapter's Creative Commons licence, unless indicated otherwise in a credit line to the material. If material is not included in the chapter's Creative Commons licence and your intended use is not permitted by statutory regulation or exceeds the permitted use, you will need to obtain permission directly from the copyright holder.

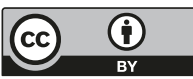

